\title{
Graded Transmission without Action Potentials Sustains Rhythmic Activity in Some But Not All Modulators That Activate the Same Current
}

\author{
-Philipp Rosenbaum and $\odot$ Eve Marder \\ Volen Center and Biology Department, Brandeis University, Waltham, Massachusetts 02454
}

Neurons in the central pattern-generating circuits in the crustacean stomatogastric ganglion (STG) release neurotransmitter both as a graded function of presynaptic membrane potential that persists in TTX and in response to action potentials. In the STG of the male crab Cancer borealis, the modulators oxotremorine, $C$. borealis tachykinin-related peptide Ia (CabTRP1a), red pigment concentrating hormone (RPCH), proctolin, TNRNFLRFamide, and crustacean cardioactive peptide (CCAP) produce and sustain robust pyloric rhythms by activating the same modulatory current $\left(I_{\mathrm{MI}}\right)$, albeit on different subsets of pyloric network targets. The muscarinic agonist oxotremorine, and the peptides CabTRP1a and RPCH elicited rhythmic triphasic intracellular alternating fluctuations of activity in the presence of TTX. Intracellular waveforms of pyloric neurons in oxotremorine and CabTRP1a in TTX were similar to those in the intact rhythm, and phase relationships among neurons were conserved. Although cycle frequency was conserved in oxotremorine and TTX, it was altered in CabTRP1a in the presence of TTX. Both rhythms were primarily driven by the pacemaker kernel consisting of the Anterior Burster and Pyloric Dilator neurons. In contrast, in TTX the circuit remained silent in proctolin, TNRNFLRFamide, and CCAP. These experiments show that graded synaptic transmission in the absence of voltage-gated $\mathrm{Na}^{+}$current is sufficient to sustain rhythmic motor activity in some, but not other, modulatory conditions, even when each modulator activates the same ionic current. This further demonstrates that similar rhythmic motor patterns can be produced by qualitatively different mechanisms, one that depends on the activity of voltage-gated $\mathrm{Na}^{+}$channels, and one that can persist in their absence.

Key words: Cancer borealis; Cancer borealis tachykinin-related peptide 1a; oxotremorine; proctolin; red pigment concentrating hormone; stomatogastric ganglion

\section{Significance Statement}

The pyloric rhythm of the crab stomatogastric ganglion depends both on spike-mediated and graded synaptic transmission. We activate the pyloric rhythm with a wide variety of different neuromodulators, all of which converge on the same voltage-dependent inward current. Interestingly, when action potentials and spike-mediated transmission are blocked using TTX, we find that the muscarinic agonist oxotremorine and the neuropeptide CabTRP1a sustain rhythmic alternations and appropriate phases of activity in the absence of action potentials. In contrast, TTX blocks rhythmic activity in the presence of other modulators. This demonstrates fundamental differences in the burst-generation mechanisms in different modulators that would not be suspected on the basis of their cellular actions at the level of the targeted current.

\section{Introduction}

Most synaptic connections are spike mediated; that is, transmitter release requires action potentials to depolarize the presynaptic

\footnotetext{
Received Sept. 13, 2017; revised Aug. 27, 2018; accepted Aug. 29, 2018.

Author contributions: P.R. and E.M. designed research;P.R. performed research;P.R. analyzed data; P.R. and E.M. wrote the paper.

The authors declare no competing financial interests.

This research was supported by National Institutes of Health Grants NS-17813 and NS-97343. We thank Jessica Haley for help with Matlab scripts for data analysis.

Correspondence should be addressed to Eve Marder, Volen Center and Biology Department MS 013, Brandeis University, 415 South Street, Waltham, MA 02454. E-mail: marder@brandeis.edu.
}

neuron to evoke the release. Nonetheless, in some neurons, the threshold for transmitter release is relatively hyperpolarized and can be both below spike threshold and close to the resting potential (Maynard and Walton, 1975; Graubard, 1978; Graubard et al., 1980; Angstadt and Calabrese, 1991; Manor et al., 1997). Some of these neurons do spike, and transmitter release has both a graded and a spiking component. Other neurons do not appear to spike, but signal solely through graded transmission (Pearson 
and Fourtner, 1975; Burrows and Siegler, 1978; DiCaprio, 1989, 2003). Although this latter situation is rare in most animals, it is predominant in the vertebrate retina and in Caenorhabditis elegans.

It is intriguing to probe the relative roles of spike-mediated and graded transmission in neurons that release in both modes, and to ask the extent to which both modes are necessary for the normal function of the circuits in which they are found (Raper, 1979; Shu et al., 2006). This question becomes even more interesting as many neuromodulators alter the strength of both spikemediated and graded synapses (Johnson and Harris-Warrick, 1990; Johnson et al., 1995, 2011; Thirumalai et al., 2006; Zhao et al., 2011) and may do so differentially (Ayali et al., 1998). This raises the possibility that a given modulatory state could alter the balance between graded and spike-mediated release for circuit function under different circumstances.

The neurons that generate the pyloric rhythm of the crustacean stomatogastric ganglion (STG) display both spike-mediated and graded release of transmitter (Raper, 1979; Thirumalai et al., 2006). The phase relationships in the pyloric rhythm, which define the motor pattern, depend on both the intrinsic currents of the pyloric circuit neurons and the strength and time course of their synaptic connections (Hartline, 1979; Hartline and Gassie, 1979; Eisen and Marder, 1984; Harris-Warrick et al., 1995; Rabbah and Nadim, 2005; Marder and Bucher, 2007). Consequently, neuromodulators that alter the intrinsic and/or synaptic properties in the network can alter the phase of the neurons and thus the pyloric motor pattern. Many modulators, including the muscarinic agonist oxotremorine (oxo), and the peptides proctolin, red pigment concentrating hormone (RPCH), Cancer borealis tachykinin-related peptide Ia (CabTRP1a), FLRFamides, and crustacean cardioactive peptide (CCAP) can activate a robust triphasic rhythm in the isolated STG of the crab C. borealis (Hooper and Marder, 1984; Nusbaum and Marder, 1988; Weimann et al., 1993, 1997; Christie et al., 1997).

Interestingly, these modulators all activate the modulatory current $\left(I_{\mathrm{MI}}\right.$; Swensen and Marder, 2000, 2001; Gray and Golowasch, 2016; Gray et al., 2017), although each has a different set of target neurons in the STG. $I_{\mathrm{MI}}$ is a voltage-dependent nonspecific cation current that is blocked at hyperpolarized membrane potentials by extracellular $\mathrm{Ca}^{2+}$ (Golowasch and Marder, 1992; Gray and Golowasch, 2016; Gray et al., 2017). This makes $I_{\mathrm{MI}}$ ideally suited to increase the amplitude (amp) of slow-wave bursts and sustain oscillations (Sharp et al., 1993).

Previous studies in the spiny lobster Panulirus interruptus showed that, after blocking action potentials with tetrodotoxin (TTX), graded transmission is sufficient to generate a pyloric rhythm after the application of dopamine or anterior nerve stimulation (Raper, 1979; Anderson and Barker, 1981; HarrisWarrick and Flamm, 1987). We study the effects of six modulators on the pyloric rhythm of the crab C. borealis in the presence and absence of TTX to determine the extent to which graded transmission is sufficient to maintain rhythmic activity and, if so, whether the phase relationships are similar to those seen in the presence of action potentials.

\section{Materials and Methods}

Animals. Adult male Jonah crabs (C. borealis) were obtained from Commercial Lobster. These experiments were performed between October 2014 and August 2017. Crabs were kept unfed in artificial seawater at $11^{\circ} \mathrm{C}$ in a $12 \mathrm{~h} \mathrm{light/dark} \mathrm{cycle.}$

Recordings. Before dissection, crabs were chilled on ice for $30 \mathrm{~min}$. Dissections were performed as previously described (Gutierrez and Gra- show, 2009). The preparation was kept in physiological saline at $11^{\circ} \mathrm{C}$, composed of $440 \mathrm{~mm} \mathrm{NaCl}, 11 \mathrm{~mm} \mathrm{KCl}, 13 \mathrm{~mm} \mathrm{CaCl}, 26 \mathrm{~mm} \mathrm{MgCl}_{2}, 11$ mM Trizma base, and $5 \mathrm{~mm}$ maleic acid, $\mathrm{pH}$ 7.4-7.6 (at room temperature). The isolated stomatogastric nervous system (STNS) was pinned down in a Sylgard lined dish. Vaseline wells were built around designated nerves, and bipolar steel electrodes were used for extracellular nerve recordings. Signals were differentially amplified (amplifier Model 1700, A-M Systems). The STG was desheathed before intracellular recordings. Glass microelectrodes with filament (1.5 mm outer diameter; Sutter Instrument) were pulled using a Sutter Micropipette Puller (Model P-97) and filled with electrode solution ( $10 \mathrm{mM} \mathrm{MgCl}_{2}, 400 \mathrm{~mm}$ KGluconate, 10 mM HEPES, $15 \mathrm{~mm} \mathrm{Na}_{2} \mathrm{SO}_{4}$, and $20 \mathrm{~mm} \mathrm{NaCl}$, pH 7.45; Hooper et al., 2015). Electrode resistances were between 15 and $30 \mathrm{M} \Omega$. Intracellular signals were recorded and amplified using an AxoClamp 900A Amplifier with pCLAMP 10.5 software (Molecular Devices). Neurons were recorded in either discontinuous current clamp or two electrode current clamp, and identified by their characteristic membrane potential waveform in conjunction with extracellular nerve recordings. Preparations were continuously superfused with $11^{\circ} \mathrm{C}$ saline at $6-7 \mathrm{ml} / \mathrm{min}$ using a Warner temperature-controlled Peltier device on the saline inflow to maintain temperature.

Modulator applications. After baseline recordings, modulatory input from higher order ganglia to the STG was blocked [decentralization (dc) of the STG] by substituting the saline in a Vaseline well around the stomatogastric nerve (stn) with $10^{-7}$ M TTX (Sigma-Aldrich/Tocris Bioscience) in a $750 \mathrm{~mm}$ sucrose solution. Thirty minutes after dc modulators were bath applied until a stable response was produced. Modulator concentrations were as follows: $10^{-5} \mathrm{M}$ oxotremorine (sesquifumarate salt, Sigma-Aldrich), $3 \times 10^{-5} \mathrm{M}$ pilocarpine (Sigma-Aldrich), $10^{-6} \mathrm{M}$ CabTRPla (RS Synthesis), $10^{-6} \mathrm{M}$ RPCH (Bachem), $10^{-6} \mathrm{M}$ proctolin (RS Synthesis), $10^{-6} \mathrm{M}$ TNRNFLRFamide (RS Synthesis), $10^{-6} \mathrm{M}$ CCAP (RS Synthesis), $10^{-4} \mathrm{M}$ dopamine (Sigma-Aldrich), $10^{-5} \mathrm{M}$ serotonin (Sigma-Aldrich), and $10^{-4} \mathrm{M}$ octopamine (Sigma-Aldrich). All modulators were added in saturating concentrations (for dose-response curves for oxotremorine and pilocarpine, see Bal et al., 1994; for CabTRP1a, see Christie et al., 1997; for RPCH see, Nusbaum and Marder, 1988; for proctolin, see Marder et al., 1986; for TNRNFLRFamide, see Weimann et al., 1993; for CCAP, see Weimann et al., 1997; for dopamine, serotonin, and octopamine, see Flamm and Harris-Warrick, 1986a,b). Only one modulator was studied in each experiment. Following modulator application in saline, $10^{-7} \mathrm{M}$ TTX was added to the bath. In some experiments, TTX saline without modulators was superfused before combining modulator and TTX superfusion. In these experiments, we waited until all activity ceased, and no action potentials were elicited after injecting depolarizing current. The two procedures led to the same conclusions regarding modulatory effects in TTX. To look at the effect of modulators in TTX on the isolated pacemaker neurons, we blocked glutamatergic synapses with $10^{-5} \mathrm{M}$ picrotoxin (PTX; Sigma-Aldrich).

Synaptic strength measurements. To compare the synaptic strength between the Lateral Pyloric (LP) and Pyloric Dilator (PD) neurons, we measured inhibitory postsynaptic potential (IPSP) amplitudes in different conditions. The strength of spike-mediated IPSPs was determined by measuring the amplitude of the first LP-evoked IPSP in PD neurons during ongoing pyloric activity, with the PD neuron at $-50 \mathrm{mV}$. In some experiments, the LP neuron was hyperpolarized to allow it to spike only once per burst to evoke a single IPSP. When the LP neuron was not spiking following decentralization, short depolarizing current pulses of varying length and duration were applied to elicit single spikes. Responses after decentralization and after modulator application were compared. To measure graded synaptic transmission, the presynaptic neuron was held at $-60 \mathrm{mV}$ and depolarized for $500 \mathrm{~ms}$ to $-20 \mathrm{mV}$ to evoke graded release (Manor et al., 1997; Zhao et al., 2011). Postsynaptic neurons were held at $-50 \mathrm{mV}$, and responses in TTX only and modulator and TTX were compared (see Ayali et al., 1998; Thirumalai et al., 2006; Zhao et al., 2011)

Data analysis. One hundred twenty seconds of data were analyzed in each condition. Data were analyzed using pCLAMP version 10.5, Spike2 version 7, Microsoft Excel 2010, and MatLab 2016 (MathWorks). Overlays of intracellular traces in Figures 4 and 5 were generated in Spike2 software, 


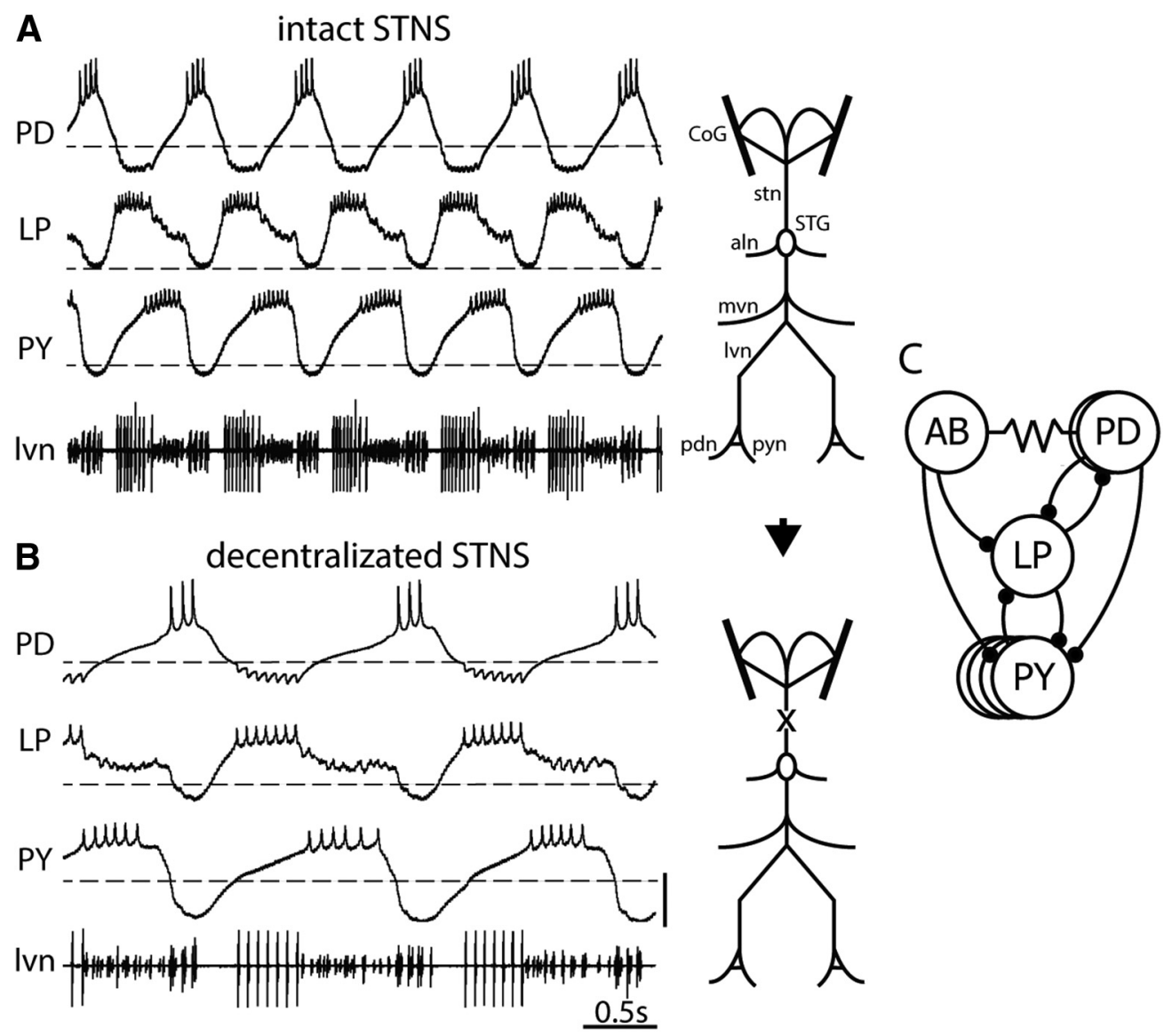

Figure 1. The triphasic pyloric rhythm before and after decentralization. $A$, Intracellular recordings of the $P D, L P$, and PY neurons, and extracellular recording of the Ivn. On the right, a schematic overview of the intact STNS. $\boldsymbol{B}$, The pyloric rhythm slowed after decentralization. Right side, The stn was blocked to abolish modulatory descending input to the STG. C, Simplified pyloric circuit. The resistor symbol between $A B$ and $P D$ shows an electrical synapse. All other synapses are inhibitory. Each circle represents one neuron. aln, Anterior lateral nerve; mvn, median ventricular nerve; pdn, PD nerve; pyn, pyloric nerve. Calibration: vertical lines, $20 \mathrm{mV}$; dashed lines, $-50 \mathrm{mV}$.

and spikes were substituted with a horizontal line, using custom-written scripts. For the phase relationship plots in Figures 4 and 5, we measured the onset and offset of PD, LP, and Pyloric (PY) neuron activity with the same method for the spiking and nonspiking data at the membrane potential threshold for spike initiation (MatLab 2016).

When presented, the boxplots show the median and the first and third quartile of the data, with whiskers extending to the most extreme data points. Comparisons of oscillation amplitudes, resting membrane potentials (rmps), and synaptic strengths were statistically tested with paired $t$ tests. Rhythm frequencies were compared and statistically tested using one-way ANOVAs with multiple comparisons and phase relationship on- and off-phases with two-way ANOVAs (MatLab 2016). In all figures, significance at $p<0.05\left(^{*}\right)$ and $p<0.001\left(^{* * *}\right)$ is reported with asterisks. Exact $p$ values, as well as $F$ values, df values, and the number of experiments $(N)$ are given in the figure legends.

\section{Results}

The STG of the crab C. borealis contains 26-27 neurons (Kilman and Marder, 1996) and produces the pyloric rhythm, a robust triphasic rhythm with a frequency of $\sim 1 \mathrm{~Hz}$, both in the animal (Soofi et al., 2014), and when the complete STNS [including the paired commissural ganglia (CoGs) and a single esophageal ganglion] is placed in a dish (Fig. 1). The pyloric rhythm activates muscles responsible for the filtering of food in the foregut of the animal and is continuously active. Figure $1 A$ shows simultaneous intracellular recordings from the PD, LP, and PY neurons, together with an extracellular recording from the lateral ventricular nerve (lvn), which contains the axons of all of these units. These neurons fire in a characteristic sequence: $\mathrm{PD} / \mathrm{LP} / \mathrm{PY}$. Figure $1 C$ is a simplified connectivity diagram for the pyloric rhythm (Marder and Bucher, 2007). There are two PD neurons in each STG that are electrically coupled to the single Anterior Burster (AB) neuron, which together form a "pacemaker kernel" for the pyloric rhythm. Both the AB and PD neurons inhibit the LP and PY neurons (Fig. 1C; Eisen and Marder, 1982). The LP and PY neurons fire on rebound from that inhibition as a consequence of the dynamics of their membrane currents and the inhibition, producing the characteristic pyloric rhythm (Maynard, 1972; Hartline, 1979; Hartline and Gassie, 1979; Selverston and Miller, 1980; Miller and Selverston, 1982; Harris-Warrick et al., 1995; Rabbah and Nadim, 2005).

When neuromodulatory inputs to the STG are removed, either by cutting or blocking the stomatogastric nerve, which sends projections to the STG, the pyloric rhythm slows or stops (Russell, 1979; Hamood et al., 2015). Figure $1 B$ shows this effect for the preparation shown in Figure $1 A$. A large body of previous work had demonstrated that many neuromodulators can strongly activate or otherwise alter the pyloric rhythm in decentralized preparations (Hooper and Marder, 1984; Marder and Calabrese, 1996). Here, we applied a modulator to decentralized preparations and then sequentially added TTX to determine whether the circuit effects of the modulators persisted in the presence of TTX (Fig. 2A). 
A

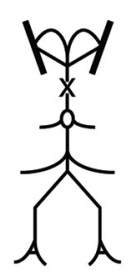

B<smiles>C=C(CC)CCC(=C)CCC(=C)CCCC(=O)c1ccccc1</smiles>

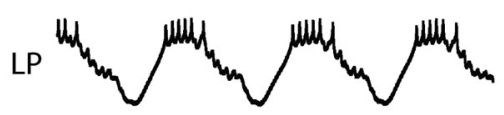

C

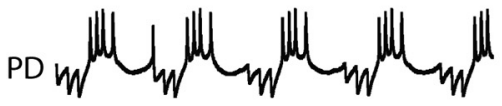

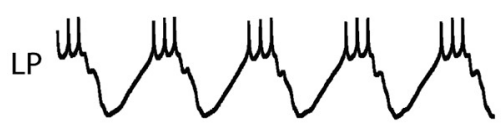

D<smiles>C#CC(C)CNC(=C)CNC(=C)CNC(=C)CP</smiles>

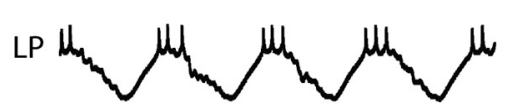

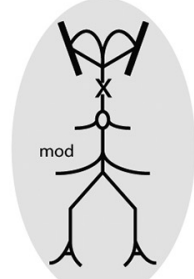

oxotremorine
oxotremorine+TTX
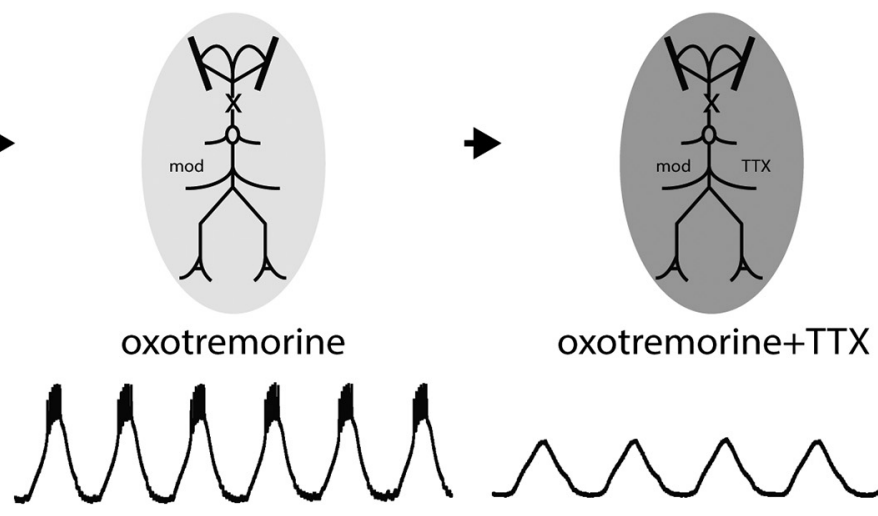


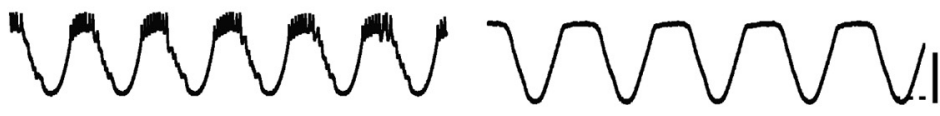

CabTRP1a

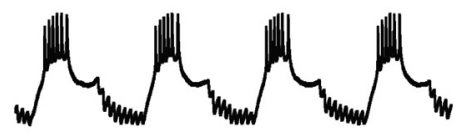

CabTRP1a+TTX

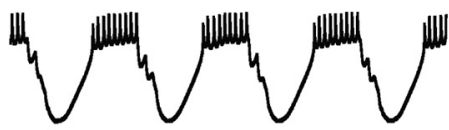

$\mathrm{RPCH}$

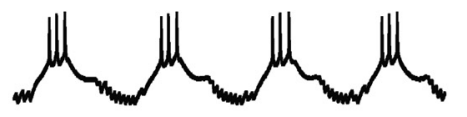

mon

$\mathrm{RPCH}+\mathrm{TTX}$
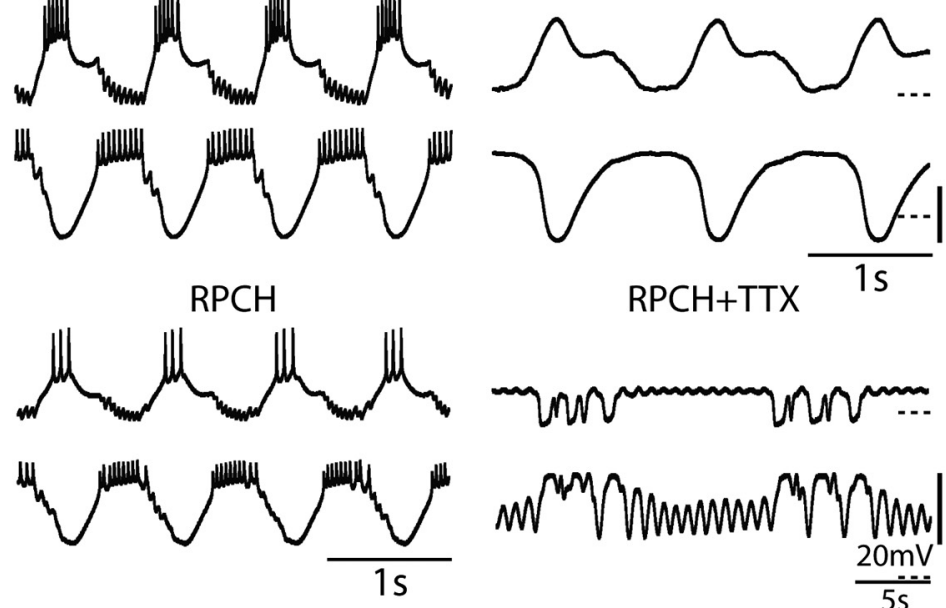

Figure 2. Effects of modulators and modulators in TTX on the pyloric rhythm. $A$, Schematic of the STNS during different experimental conditions (from left to right), as follows: decentralized, modulator application, modulator and TTX application. $\boldsymbol{B}-\boldsymbol{D}$, Intracellular recordings of the PD neuron and LP neuron in the three different conditions. In the decentralized preparation, the frequency decreased, and phase relationships remained similar (all left panels). $\boldsymbol{B}$, Application of the muscarinic agonist oxotremorine strongly activates the pyloric rhythm and increases burst frequency. Coapplication of oxotremorine and TTX abolishes spiking but leaves the slow-wave oscillations almost unchanged. C, CabTRP1a produces a strong pyloric rhythm, after addition of TTX the slow-wave remains, but the rhythm slows. D, RPCH produces a robust pyloric rhythm, and after the addition of TTX oscillations with two time components emerge. Calibration: vertical lines, $20 \mathrm{mV}$; dashed lines, $-50 \mathrm{mV}$.

\section{Some modulator rhythms persist in TTX}

Muscarinic cholinergic agonists strongly activate the rhythmic activity of the STG (Marder and Paupardin-Tritsch, 1978; Marder and Eisen, 1984b; Elson and Selverston, 1992; Bal et al., 1994). Figure $2 B$ shows intracellular recordings from the $P D$ and LP neuron, first in the control decentralized condition, then in oxotremorine (a muscarinic cholinergic agonist), and then in oxotremorine plus TTX. As shown previously, oxotremorine increased the cycle frequency of the pyloric rhythm, as well as the amplitude of the PD slow-wave bursts and the number of the PD and LP spikes/burst. When TTX was added, still in the presence of oxotremorine, note that the rhythmic alternations between PD and LP continued, because these neurons depolarized out of phase with each other, without action potentials. Muscarinic agonists elicited stable rhythms in 21 of 21 preparations (oxotremorine, $N=17$; pilocarpine, $N=4$ ).

CabTRP1a is a tachykinin-related peptide isolated from C. borealis (Christie et al., 1997) that is found in descending modulatory inputs to the STG (Blitz et al., 1999; Wood et al., 2000; Stein et al., 2007). Figure $2 C$ shows that CabTRP1a also increases the ampli- tude of the slow-wave oscillations and the numbers of action potentials/burst in both the PD and LP neurons. As with oxotremorine, the slow-wave alternations in CabTRPla persisted in TTX, again with the depolarizations and hyperpolarizations in the PD and LP out of phase with each other. CabTRP1a elicited rhythms in TTX in 13 of 14 preparations.

RPCH also activates the pyloric rhythm in crabs (Nusbaum and Marder, 1988), as well as strongly enhances synaptic transmission in lobsters (Dickinson et al., 1990; Thirumalai et al., 2006). Figure 2D shows the effects of RPCH in control saline and then in the presence of TTX. Note that in TTX there were slow and alternating patterns of activity between the PD and LP neurons, but these patterns are quite different from those seen in oxotremorine and CabTRP1a. These or similar patterns were seen in 19 of 30 experiments. The diversity of patterns seen in RPCH are further analyzed elsewhere (P. Rosenbaum, unpublished observations).

\section{Some modulator rhythms are blocked in TTX}

Not all modulators that activate or enhance the pyloric rhythm are capable of producing alternating patterns of activity in TTX. 
A

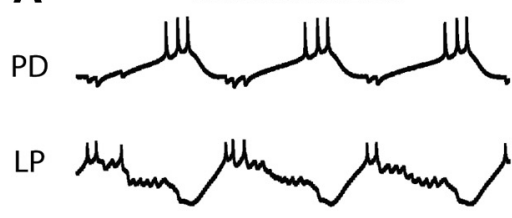

B

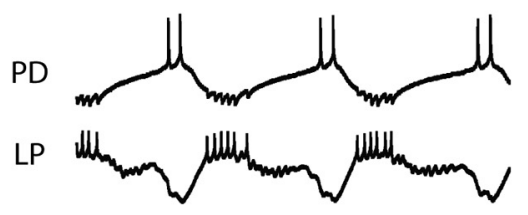

C

PD

LP

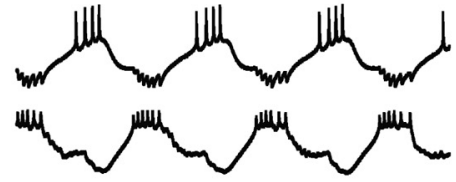

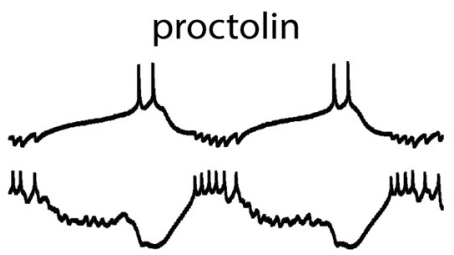

TNRNFLRFamide

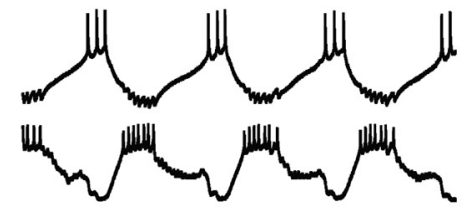

CCAP

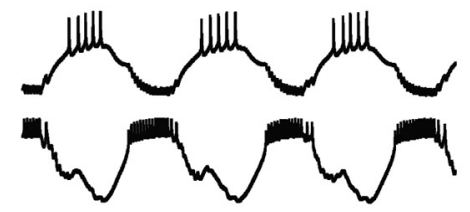

proctolin+TTX

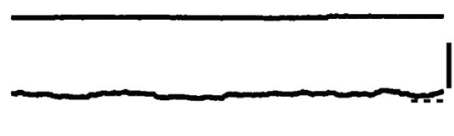

TNRNFLRFamide+TTX

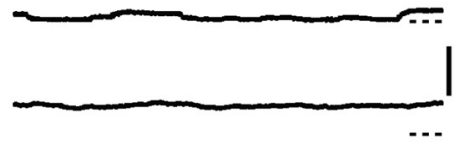

CCAP+TTX

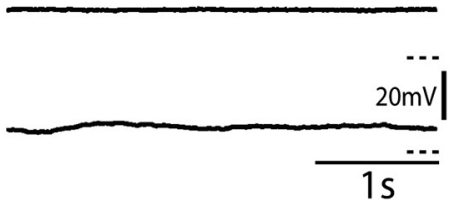

Figure 3. Effects of modulators and modulators in TTX on the pyloric rhythm. $A-C$, Intracellular recordings of the PD neuron and LP neuron following decentralization (left) and modulator application (middle), and after adding TTX (right). In the decentralized preparation, the frequency decreased, and phase relationships remained similar (all left panels). Proctolin, TNRNFLRFamide, and CCAP produce a robust pyloric rhythm, but activity ceases after adding TTX. Calibration: vertical lines, $20 \mathrm{mV}$; dashed lines, $-50 \mathrm{mV}$.

Figure 3 shows that in the presence of TTX preparations in proctolin (Fig. 3A), TNRNFLRFamide (Fig. 3B), and CCAP (Fig. 3C) became silent. (In TTX, activity was seen in 0 of 5 experiments in proctolin; in 0 of 6 experiments in TNRNFLRFamide; in 0 of 7 experiments in CCAP.) Interestingly, oxotremorine, CabTRP1a, proctolin, RPCH, CCAP, and TNRNFLRFamide all activate the same voltage-dependent inward current, $I_{\mathrm{MI}}$, in various STG neurons, among them the bursting pacemaker neuron, AB (Golowasch and Marder, 1992; Swensen and Marder, 2000, 2001; Garcia et al., 2015; Gray and Golowasch, 2016; Gray et al., 2017), so the differences between the results shown in Figures 2 and 3 were unexpected.

In the lobster $P$. interruptus, the amine dopamine strongly activates the pyloric rhythm (Flamm and Harris-Warrick, 1986a). In contrast, in crabs, high concentrations of dopamine have been seen to "crash" the rhythm, and the alternating pattern of activity in the LP and PD neurons is lost (Marder and Weimann, 1992). We replicated those results in five experiments in which we applied $10^{-4} \mathrm{M}$ dopamine. In one experiment, dopamine elicited a weak triphasic rhythm, with a low-amplitude slow wave. In the other four experiments, PD and LP fired tonically after dopamine application and turned silent within a few minutes. In six experiments in which dopamine and TTX were coapplied, PD and LP depolarized by $\sim 5 \mathrm{mV}$ but remained silent otherwise (data not shown). Octopamine, another amine, was able to produce triphasic patterns in the dc STG, but the STG became silent after adding TTX ( 0 of 3 experiments; data not shown).

\section{Characterization of the muscarinic-induced rhythms in the} presence and absence of TTX

We were curious to compare quantitatively the triphasic rhythms generated by muscarinic agonists (oxotremorine, $N=17$; pilocarpine, $N=4$ ) in TTX with those seen in the presence of action potentials. Figure $4 A$ shows overlaid normalized and averaged PD, LP, and PY intracellular traces from 20 cycles in oxotremo- rine (black, spikes removed) and oxotremorine and TTX (gray). Comparing the oscillation amplitudes and trough membrane potentials of the three pyloric neurons in oxotremorine with and without TTX, no significant differences were found in the oscillation amplitudes. Nonetheless, the PD and LP trough membrane potentials were different (Table 1).

We quantified pyloric cycle frequencies in the intact STNS, following decentralization, and subsequently in oxotremorine, and in oxotremorine with TTX (Fig. 4B). As commonly occurs, the pyloric cycle frequency decreased significantly after decentralization $(N=16$ : intact, $1.18 \pm 0.37 \mathrm{~Hz}$; decentralized, $0.57 \pm$ $0.45 \mathrm{~Hz} ; p=0.0001$; Hamood and Marder, 2015). After the application of oxotremorine, oscillations returned to a frequency comparable to the intact STNS and remained there after adding TTX (oxo, $1.24 \pm 0.32 \mathrm{~Hz}$; oxo + TTX, $1.15 \pm 0.27 \mathrm{~Hz}$ ). The phase relationships of PD, LP, and PY, which represent the normalized time within one pyloric cycle when each neuron is active, are shown in Figure $4 C$. These were largely conserved across conditions, whereas PY phases were more variable. Most notably, PY burst onsets in oxotremorine occurred earlier after adding TTX, which accounts for the flatter waveform shape in the latter condition.

\section{Characterization of CabTRP1a-induced rhythms in the presence and absence of TTX}

Figure 5 shows the membrane potential waveforms during pyloric activity in CabTRP1a in the presence and absence of TTX. In 13 of 14 experiments in which CabTRP1a and TTX were coapplied, a triphasic rhythm was observed. In Figure $5 A$, the average waveforms of the three pyloric neurons in CabTRP1a (spikes removed), and CabTRP1a + TTX were compared. In the superimposed traces, the similar shape of the membrane potential is apparent (black, CabTRP1a; gray, CabTRP1a + TTX). Except for the $\mathrm{PD}$ trough membrane potential, the oscillation amplitudes and trough membrane potentials did not change significantly 
A

oxotremorine

oxotremorine+TTX


PY



B

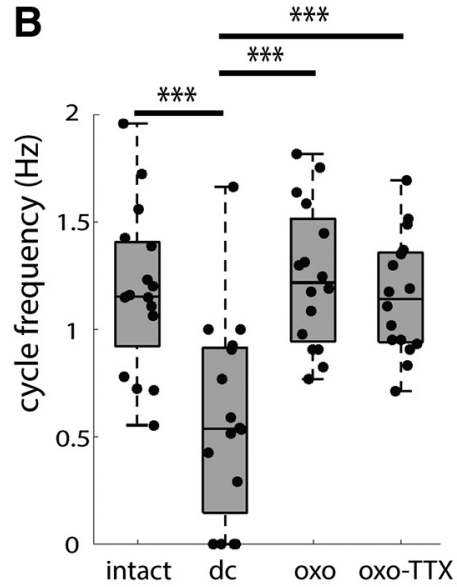

C phase relationships

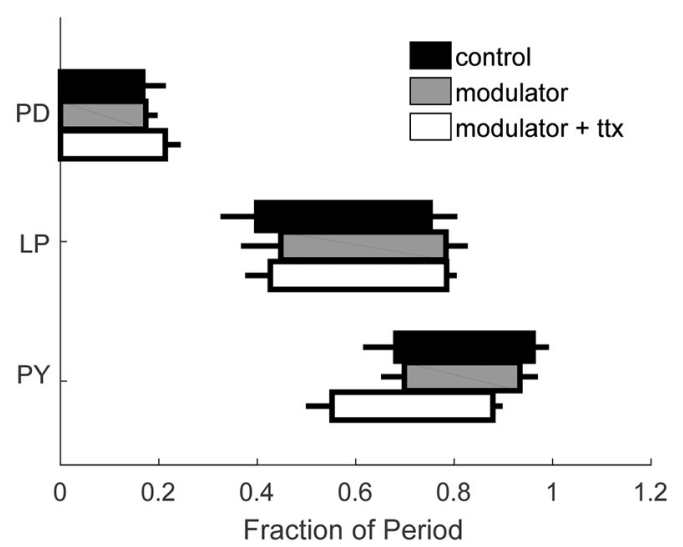

Figure 4. Comparison of oscillations in oxotremorine and oxotremorine plus TTX. A, Averaged intracellular traces of PD, LP, and PY from 20 oscillations in oxotremorine (black) and oxotremorine and TTX (gray) were normalized to three PD cycles and overlaid. Spikes were digitally removed from the oxotremorine traces to facilitate direct comparison with the TTX traces (see Materials and Methods). Calibration: vertical line, $20 \mathrm{mV}$; dashed lines, $-50 \mathrm{mV}$. B, Comparison of the pyloric frequency in the intact STNS, after dc, in oxotremorine, and in oxotremorine + TTX. $N=16$; Box plots show the median and first and third quartiles of data, and whiskers extend to the minima/maxima. Each point reports the averaged data of one experiment. One-way ANOVA: ${ }^{* * *} p<0.001$ (intact-decentralized, $p=0.0001$; intact-0xo, $p=0.9594$; intact-0x0-TTX, $p=0.9974 ; \mathrm{dc}-0 \times 0, p=0.0000 ; \mathrm{dc}-0 \mathrm{x} 0$-TTX, $p=0.0002 ; 0 \times 0-0 \times 0-\mathrm{TTX}, p=0.9003 ; F=11.5 ; \mathrm{df}=15$ ). C, Phase relationships of PD, LP, and PY in the different conditions $(N=5)$. No significant differences; two-way ANOVA PD: off control-0xo, $p=0.993 ;$ control-0xo + TTX, $p=0.2764 ; 0 \times 0$-0xo + TTX, $p=$



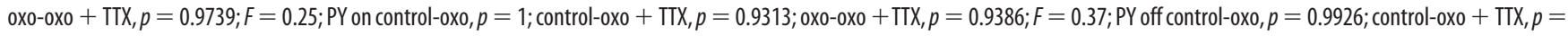
$0.9989 ; 0 \times 0-0 \times 0+\mathrm{TTX}, p=0.9992 ; F=0.87, \mathrm{df}=4$.

Table 1. Mean oscillation amplitudes and trough membrane potentials for modulator only and modulator + TTX conditions in PD, LP, and PY neurons

\begin{tabular}{lrccc}
\hline & Oxotremorine & 0xotremorine + TTX & CabTRP1a & CabTRP1a + TTX \\
\hline PD amp (mV) & $19.8 \pm 6.1$ & $20.6 \pm 9$ & $18.2 \pm 4.8$ & $17.6 \pm 10.1$ \\
PD tmp (mV) & $-55.7 \pm 5.3$ & $-52.2 \pm 5.6^{*}$ & $-53.4 \pm 4.3$ & $-48.2 \pm 6.4^{*}$ \\
LP amp (mV) & $17.7 \pm 3.9$ & $20.5 \pm 7.8$ & $17.8 \pm 5.1$ & $17.3 \pm 9.2$ \\
LP tmp (mV) & $-54.1 \pm 3.4$ & $-55 \pm 3.4^{*}$ & $-52.5 \pm 6.4$ & $-50.4 \pm 7.8$ \\
PY amp (mV) & $20.2 \pm 5.9$ & $24.2 \pm 10.3$ & $12.8 \pm 6.4$ & $6.9 \pm 8$ \\
PY tmp (mV) & $-58.4 \pm 1.5$ & $-60.2 \pm 2.6$ & $-56.9 \pm 4.7$ & $-56.1 \pm 4.8$ \\
\hline
\end{tabular}

Slow-wave amplitudes were measured without action potentials. tmp, Trough membrane potential (the most hyperpolarized point of the membrane potential excursion).

${ }^{*}$ oxo vs oxo + TTX: PD amp, $p=0.856 ; \mathrm{PD}$ tmp $, p=0.0059, \mathrm{df}=13, \mathrm{~N}=14 ; \mathrm{LP}$ amp,$p=0.1775 ; \mathrm{LP}$ tmp,$p=$ $0.0315 ; \mathrm{df}=14, N=15 ; \mathrm{PY}$ amp, $p=0.1893 ; \mathrm{PY}$ tmp,$p=0.07 ; \mathrm{df}=4, N=5$. CabTRP1a vs CabTRP1a + TTX: $\mathrm{PD}$ amp,$p=0.7917 ; \mathrm{PD}$ tmp,$p=0.0013 ; \mathrm{df}=12, N=13 ; \mathrm{LP}$ amp,$p=0.8147 ; \mathrm{LP}$ tmp,$p=0.0576 ; \mathrm{df}=11$, $N=12 ; \mathrm{PY}$ amp, $p=0.1271 ; \mathrm{PY}$ tmp,$p=0.6617 ; \mathrm{df}=6, N=7$ (paired $t$ test).

after adding TTX (Table 1). The traces in Figure $2 C$ suggest a slower cycle frequency in CabTRP1a after adding TTX. The box plots in Figure $5 B$ show the typical significant decrease in frequency following decentralization $(N=14$; intact, $1.21 \pm 0.34$ $\mathrm{Hz}$; decentralized, $0.65 \pm 0.43 \mathrm{~Hz} ; p=0.0003)$. The application of CabTRPla did not significantly increase the frequency of the rhythm after decentralization (CabTRP1a $0.83 \pm 0.2 \mathrm{~Hz}$ ). After adding TTX, the rhythm slowed significantly $(0.5 \pm 0.29 \mathrm{~Hz})$. Thus, pyloric rhythms in CabTRP1a were slower than in oxotremorine $(1.24 \pm 0.32 \mathrm{~Hz})$ and oxotremorine + TTX $(1.15 \pm$ $0.27 \mathrm{~Hz}$ ). Phase relationships were conserved across the four conditions, with more variability in CabTRP1a and TTX (Fig. 5C). The only significant differences found were at the end of LP activity between the control and the CabTRP1a + TTX condition (Fig. 5C, legend).

The results in Figures 2, 3, 4, and 5 suggest that under some modulatory conditions a coordinated triphasic rhythm can be generated without action potentials. Thus, in principle, graded synaptic transmission is sufficient to maintain stable phase relationships between the pyloric neurons. Although the frequency of the rhythm is maintained in both oxotremorine and CabTRP1a in TTX, it is slower in CabTRP1a and TTX.

\section{Modulation of spike-mediated and graded transmission}

The only direct feedback to the pacemaker kernel AB-PD-PD is the inhibitory LP-PD synapse, which can contribute to the frequency of the rhythm under some, but not all, conditions (Selverston and Moulins, 1985; Ayali and Harris-Warrick, 1999; Thirumalai et al., 2006). To determine the influence of modulation on this synapse, the strength of spike-mediated synaptic transmission between LP and PD was determined by measuring LP-evoked IPSP amplitudes in the PD neurons following decentralization and oxotremorine or CabTRP1a application. On average, spike-mediated IPSP amplitudes increased significantly after adding oxotremorine $(N=9$; decentralized, $2.3 \pm 1.2 \mathrm{mV}$; oxo, $2.9 \pm 1.2 \mathrm{mV} ; p=0.0053$; Fig. $6 \mathrm{~A}$, left side) and in CabTRP1a $(N=9$; decentralized, $3.2 \pm 1.1 \mathrm{mV}$; CabTRP1a, $4.9 \pm 1.2 \mathrm{mV} ; p=0.002$; Fig. $6 \mathrm{~A}$, right side; see figure legend).

Graded synaptic strength was measured both from the LP neuron to the $\mathrm{AB} / \mathrm{PD}$ neurons and from the $\mathrm{AB} / \mathrm{PD}$ neurons to the LP neuron in the presence of TTX. In these experiments, the presynaptic neuron was depolarized from -60 to $-20 \mathrm{mV}$ for $500 \mathrm{~ms}$, and the responses were measured at $-50 \mathrm{mV}$ in the postsynaptic neuron (Fig. $6 B$ ). The depolarization from -60 to $-20 \mathrm{mV}$ corresponds approximately to the maximal range of the membrane potential oscillations that occur during an ongoing pyloric rhythm. Graded synaptic inhibition from the LP neuron to the PD neuron did not increase significantly after either oxotremorine or CabTRP1a application (Fig. 6C,D, left sides; oxo: PD TTX, $10.4 \pm 2.6 \mathrm{mV}$; oxo + TTX, $12 \pm 2.6 \mathrm{mV} ; N=5$; CabTRP1a: TTX, $7.15 \pm 4.5 \mathrm{mV}$; CabTRP1a + TTX, $10.9 \pm 2.8$ $\mathrm{mV} ; \mathrm{N}=4)$. Graded transmission from the PD neuron to the LP neuron also showed no change in CabTRP1a (Fig. 6D, right; TTX, $6.43 \pm 2.5 \mathrm{mV}$; CabTRP1a + TTX, $5.98 \pm 1.7 \mathrm{mV})$. In contrast, oxotremorine strongly reduced the graded inhibition evoked in LP by PD depolarization (TTX, $10.3 \pm 1.7 \mathrm{mV}$; oxo + TTX, $1.6 \pm 1.4 \mathrm{mV} ; p=0.002$; Fig. $6 D$, legend). This might in part be due to the decreased input resistance during the ongoing oscillations and the synaptic input LP receives. 
A
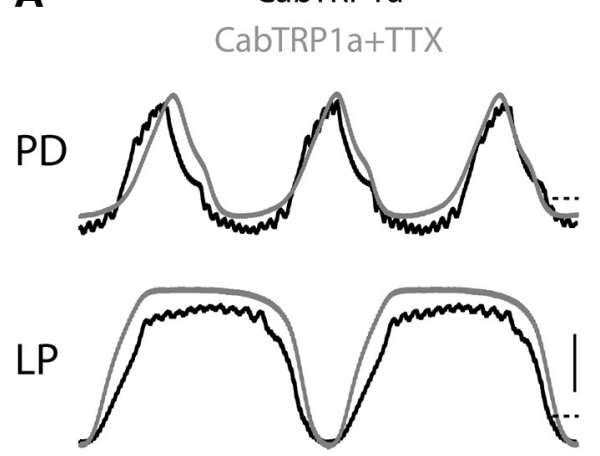

PY

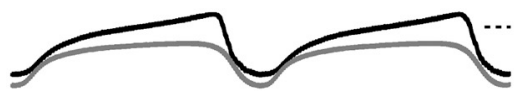

B

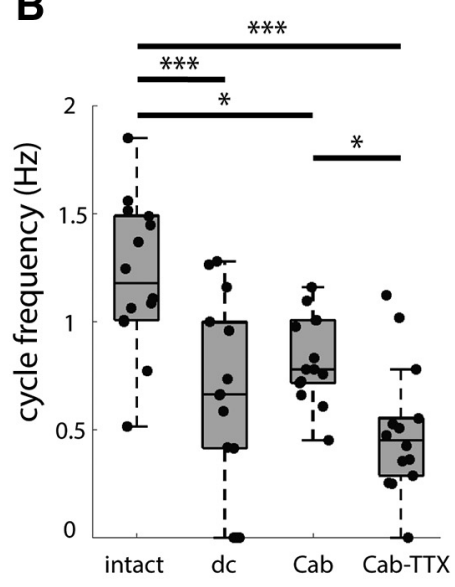

\section{C \\ phase relationships}

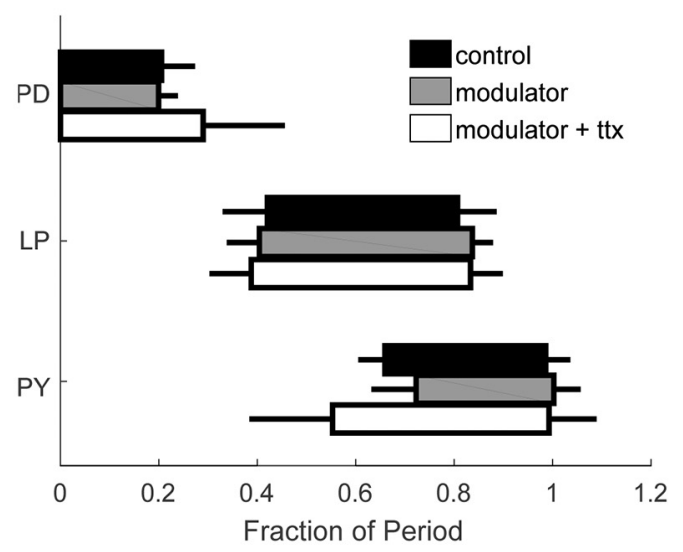

Figure 5. Comparison of oscillations in CabTRP1a (Cab) and CabTRP1a + TTX. A, Normalized and averaged intracellular traces of PD, LP, and PY neurons from 20 oscillations in CabTRP1a (black) and CabTRP1a and TTX (gray) were overlaid. Spikes were removed in CabTRP1a. Calibration: vertical bars, $20 \mathrm{mV}$; horizontal bars, $-50 \mathrm{mV}$. B, Comparison of the frequency in the intact STNS, after $\mathrm{dc}$, CabTRP1a, and CabTRP1a + TTX.N = 14. Box plots show the median and first and third quartiles of data, and whiskers extend to the minima/maxima. Each point correlates to the averaged data of one experiment. ${ }^{*} p<0.05,{ }^{* * *} p<0.001$ (intact-dc, $p=0.0003$; intact-CabTRP1a, $p=0.0182$; intact-CabTRP1a + TTX, $p=0.0000 ; \mathrm{dc}-$ CabTRP1a, $p=0.5333$; dc-CabTRP1a-TTX, $p=0.6041$; CabTRP1a-CabTRP1a $+\mathrm{TTX}, p=0.05 ; F=11.79 ; \mathrm{df}=13) . C$, Phase relationships of PD, LP, and PY neurons in the different conditions $(N=6)$. The only significant difference was between LP-off control and CabTRP1a + TTX (two-way ANOVA PD off control-CabTRP1a, $p=0.9957$; control-CabTRP1a + TTX, $p=0.2530$; CabTRP1a-CabTRP1a + TTX, $p=0.3507 ; F=1.56 ;$ LP on control-CabTRP1a, $p=0.9417$; control-CabTRP1a + TTX, $p=0.1868 ;$ CabTRP1a-CabTRP1a + TTX, $p=0.4222 ; F=1.79 ;$ LP off control-CabTRP1a, $p=0.7701 ;$ control-CabTRP1a + TTX, $p=$ 0.0314*; CabTRP1a-CabTRP1a + TTX, $p=0.1793 ; F=3.8 ;$ PY on control-CabTRP1a, $p=0.8285 ;$ control-CabTRP1a + TTX, $p=0.295 ;$ CabTRP1a-CabTRP1a + TTX, $p=0.7601 ; F=1.31 ;$ PY off control-CabTRP1a, $p=0.8694$; control-CabTRP1a + TTX, $p=0.0745$; (abTRP1a-CabTRP1a + TTX, $p=0.2679 ; F=2.78, \mathrm{df}=5$ ).

\section{Effects of current injection into PD and LP neurons}

Muscarinic agonists can induce rhythmic activity in all pyloric neurons in the Cape lobster (Bal et al., 1994). To investigate how rhythms in oxotremorine, as well as in CabTRP1a and TTX, are likely generated in the Jonah crab, the effects of depolarizing and hyperpolarizing the pacemaker neurons and LP neuron were examined. When the $\mathrm{AB}$ neuron or $\mathrm{PD}$ neuron was hyperpolarized, the rhythm slowed (Fig. 7A; $N=6$ ). When the PD neuron was depolarized, the frequency of the rhythm increased (Fig. $7 B ; N=8$ ). As previously reported for the effect of the LP neuron on pyloric cycle frequency in the spiny and Maine lobsters (Ayali and HarrisWarrick, 1999; Thirumalai et al., 2006) in three experiments, hyperpolarization of the LP neuron did not influence the cycle frequency of the PD neurons (Fig. $7 C$ ), but in two experiments the cycle frequency did increase due to the absence of LP inhibition of PD (data not shown). LP depolarization led to a greater PD inhibition and thus to a slower frequency (Fig. $7 D ; N=5$ ). Similar results were obtained in CabTRPla in the presence of TTX (data not shown).

To determine whether pacemaker activation alone is sufficient to generate oscillations in oxotremorine and CabTRP1a or whether interaction between pyloric neurons is necessary, we pharmacologically isolated the pacemaker ensemble using $10^{-5}$ M PTX, which blocks the glutamatergic inhibitory synapses in the STG (Marder and Paupardin-Tritsch, 1978; Bidaut, 1980; Marder and Eisen, 1984a). Because the LP-PD synapse is the only chemical synaptic connection back to the pacemaker ensemble from the other pyloric circuit neurons, and the LP-PD synapse is glutamatergic (Marder and Eisen, 1984a), the pacemaker ensemble is effectively isolated from chemical synaptic inputs from the rest of the pyloric circuit. Figure $8 A$ shows a recording from a PD and LP neuron in the simultaneous presence of oxotremorine, TTX, and PTX. Oxotremorine produced a rhythm in all of the isolated pacemakers examined $(N=8)$. The frequency of the oscillations in the preparation shown in Figure $8 A$ was unchanged before and after adding the PTX (average frequency: oxotremorine + TTX, $0.92 \pm 0.22 \mathrm{~Hz}$; oxotremorine + TTX +
PTX, $0.93 \pm 0.29 \mathrm{~Hz} ; p=0.773, \mathrm{df}=7)$. The PD oscillation amp and rmp did not change significantly between oxotremorine + TTX $(18.4 \pm 7 \mathrm{mV},-51.2 \pm 6 \mathrm{mV})$ and oxotremorine $+\mathrm{TTX}+$ PTX $(14 \pm 8.8 \mathrm{mV},-47.3 \pm 3.9 \mathrm{mV}$; amp: $p=0.093, \mathrm{df}=7$; rmp: $p=0.12, \mathrm{df}=7 ; N=8)$. The membrane potentials of the LP and PY neurons depolarized significantly after adding PTX (LP: oxotremorine + TTX, $-56.9 \pm 3.3 \mathrm{mV}$; oxotremorine + TTX + PTX, $36.6 \pm 10.2 \mathrm{mV} ; p=0.0003, \mathrm{df}=7 ; N=8$; PY: oxotremorine + TTX, $-59 \pm 1 \mathrm{mV}$; oxotremorine + TTX + PTX, $-37 \pm$ $3 \mathrm{mV} ; p=0.0017, \mathrm{df}=4 ; N=3)$.

CabTRP1a also consistently evoked rhythmic activity in the PD neurons in the presence of TTX and PTX $(N=8$; Fig. $8 B)$, although the frequencies of the isolated pacemaker in CabTRP1a were significantly lower in the presence of PTX than in the presence of CabTRP1a + TTX alone (CabTRP1a + TTX, $1.93 \pm 0.91$ Hz; CabTRP1a + TTX + PTX, $5.33 \pm 3.72 \mathrm{~Hz} ; p=0.039, \mathrm{df}=$ $7)$. The modulators that did not elicit circuit activity in TTX did not activate the pharmacologically isolated pacemaker ensemble (proctolin, $N=2$; TNRNFLRFamide, $N=3$; CCAP, $N=3$; octopamine, $N=3$ ).

Together, the activation of the pacemaker kernel by oxotremorine and CabTRP1a was sufficient to generate oscillations in the absence of spiking. This activation in combination with graded synaptic transmission between the pyloric neurons was sufficient to evoke a coordinated pyloric rhythm of appropriate frequency and phase relationships, as long as the appropriate neuromodulatory environment is present.

\section{Discussion}

\section{Modulators can promote both plasticity and stability}

It remains a mystery why brains use so many neuromodulators. It is also puzzling why the small number of neurons in the crustacean stomatogastric ganglion are modulated by more substances than there are neurons (Marder and Bucher, 2007; Marder, 2012; Marder et al., 2014). When the richness of neuromodulation of the STG initially became apparent, we argued that each modula- 

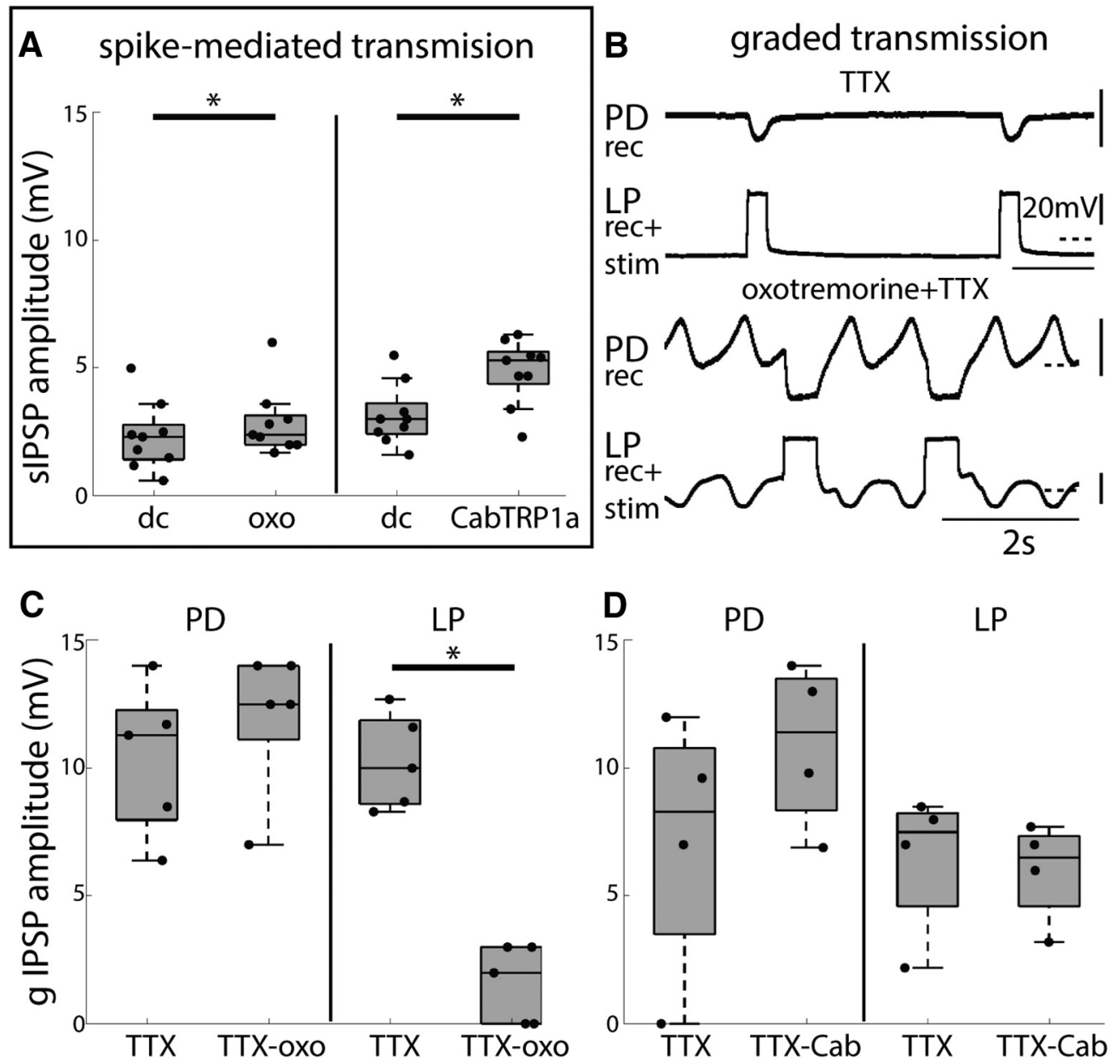

Figure 6. Spike-mediated and graded synaptic strength in oxotremorine and CabTRP1a (Cab) measured across different conditions. $\boldsymbol{A}$, Comparison of IPSP amplitudes in the PD neuron after decentralization and in oxotremorine and CabTRP1a (dc-0x0: $p=0.0053 ; \mathrm{df}=8 ; \mathrm{dc}-$ CabTRP1a: $p=0.002 ; \mathrm{df}=8$ ). $\boldsymbol{B}$, Example traces for the measurement of graded synaptic strength in TTX (first two traces) and oxotremorine + TTX (bottom two traces). The presynaptic cell (LP) was depolarized from -60 to $-20 \mathrm{mV}$, and the postsynaptic cell (PD) was held at $-50 \mathrm{mV}$. C, Amplitudes of the graded IPSP in PD and LP for TTX and oxotremorine + TTX (PD TTX-TTX + oxo: $p=0.0839 ; \mathrm{df}=4 ; \mathrm{LP}$ TTX-TTX $+0 \mathrm{xx} 0: p=0.0015 ; \mathrm{df}=4)$. D, Amplitudes of the graded IPSP in PD and LP for TTX and CabTRP1a + TTX (PD TTX-TTX + CabTRP1a: $p=0.0994 ; \mathrm{df}=3 ;$ LP TTX-TTX + CabTRP1a: $p=0.42 ; \mathrm{df}=3$ ). Box plots show the median and first and third quartiles of data, and whiskers extend to the minima/maxima. Each point correlates to the averaged data of one experiment. ${ }^{*} p<0.05$ (one-way ANOVA). rec, Recorded; sIPSP, spike-mediated IPSP; stim, stimulated.

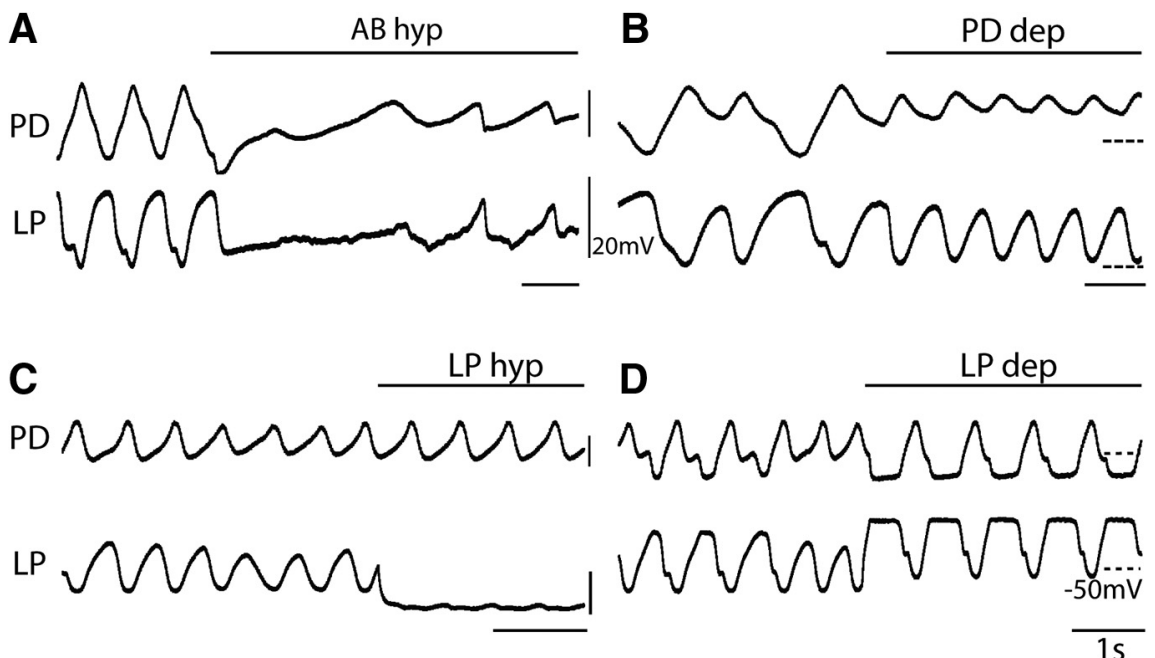

Figure 7. Current injections in TTX and oxotremorine. Intracellular recordings of PD and LP are shown. $\boldsymbol{A}$, Hyperpolarization of the pacemaker slows down the pyloric rhythm. $\boldsymbol{B}, \mathrm{PD}$ depolarization speeds up oscillation. $\boldsymbol{C}$, LP hyperpolarization has little effect on the frequency of the PD neurons. $D, L P$ depolarization leads to stronger inhibition of PD, resulting in a slower PD frequency. Calibration: dashed horizontal bars, $-50 \mathrm{mV}$; vertical bars, $20 \mathrm{mV}$. tor produces a somewhat different motor pattern, and that these variable motor patterns would confer behavioral flexibility (Dickinson and Nagy, 1983; Eisen and Marder, 1984; Hooper and Marder, 1984; Marder and Hooper, 1985; Marder et al., 1987; Dickinson et al., 1990; HarrisWarrick and Marder, 1991; Marder and Weimann, 1992).

But additionally, we now know that some modulators have similar, overlapping actions, and can act as "fail-safe" mechanisms, promoting stability of the rhythms under appropriate conditions (Marder, 2012). Moreover, some modulators have opposing cellular actions, which can help to balance inward and outward currents to sustain robust activity (Harris-Warrick and Johnson, 2010; Marder, 2012). These and other mechanisms can contribute to stable and robust performance in the population, despite significant animal-to-animal variability 


\section{A oxotremorine+TTX+PTX}

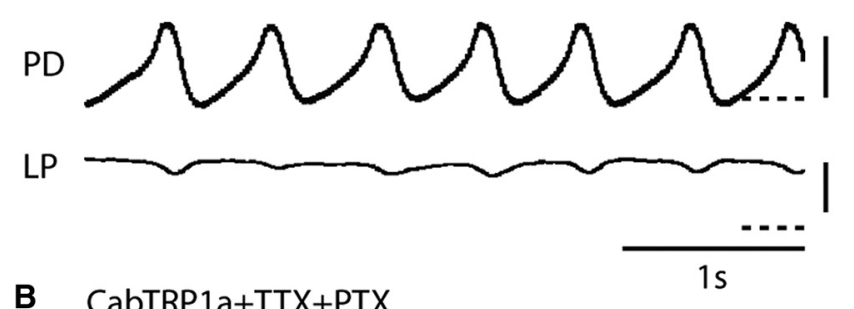

B CabTRP1a+TTX+PTX

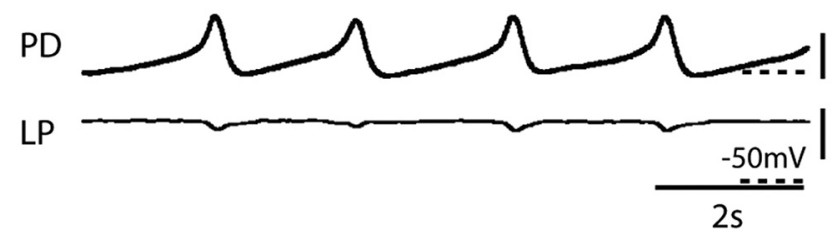

Figure 8. Activity of the pharmacologically isolated pacemaker AB-PD in TTX and either oxotremorine or CabTRP1a. $A$, In the presence of oxotremorine, TTX, and PTX, the rhythm in PD persists. Note the small PD-LP inhibition in the LP traces. $\boldsymbol{B}$, In CabTRP1a, TTX, and PTX, pacemaker oscillations persist. Calibration: dashed horizontal bars, $-50 \mathrm{mV}$; vertical bars, $20 \mathrm{mV}$.

(Goaillard et al., 2009; Grashow et al., 2009, 2010; Hamood and Marder, 2014, 2015; Hamood et al., 2015).

Many modulators, including oxotremorine, CabTRP1a, $\mathrm{RPCH}$, proctolin, TNRNFLRFamide, and CCAP, generate robust pyloric rhythms when applied to STG preparations from which endogenous modulatory substances have been removed. These six modulators in particular all activate $I_{M I}$ (Swensen and Marder, 2000; Gray and Golowasch, 2016; Gray et al., 2017), although the neuronal targets and the current densities activated by each substance are different (Swensen and Marder, 2001; Garcia et al., 2015). Thus, although the activation of the pyloric rhythm by each of these substances benefits from their actions on the same current, the contribution of each of these substances to maintaining an ongoing and robust rhythm will be different. One consequence of this is that the effects of TTX on the rhythms seen in each of the modulators are different (Fig. 2).

\section{Variable responses to block of the fast $\mathrm{Na}^{+}$current}

An insight into the variable effects of TTX on the pyloric rhythm as a function of the neuromodulator present has come from studies of the effects of TTX on bursting in the isolated $\mathrm{AB}$ neurons in different modulators (Harris-Warrick and Flamm, 1987; Epstein and Marder, 1990). In P. interruptus, AB neuron bursting persists in the presence of TTX and dopamine, but in the presence of serotonin and octopamine, AB neuron bursting is lost in TTX. Changes in bath $\mathrm{Ca}^{2+}$ concentration suggested that the $\mathrm{Na}^{+}$and $\mathrm{Ca}^{2+}$ contributions to the inward current that drives the upswing of the burst were different in different modulators (HarrisWarrick and Flamm, 1987). This interpretation was supported by a computational model (Epstein and Marder, 1990) that shows that the ratio of the $\mathrm{Na}^{+}$and $\mathrm{Ca}^{2+}$ currents responsible for the burst inward current could account for the results seen in the study by Harris-Warrick and Flamm (1987). The mechanism by which dopamine oscillations are generated is partially understood, suggesting that dopamine evokes calcium release from intracellular stores, activating a nonselective calcium current that depolarizes the $\mathrm{AB}$ neuron to initiate oscillations (Kadiri et al., 2011).

In other preparations, rhythmic activity also persists in the presence of TTX. NMDA can activate oscillatory activity in TTX in a number of spinal cord and other vertebrate preparations
(Sigvardt et al., 1985; Grillner et al., 1987; Prime et al., 1999; MacLean and Schmidt, 2001; Bonansco and Buño, 2003). There is an obvious similarity between the oscillator activation by NMDA and that produced by the modulators that act on $I_{\mathrm{MI}}$ because the current-voltage curve activated by $I_{\mathrm{MI}}$ is similar to that of the NMDA receptor (Golowasch and Marder, 1992; Swensen and Marder, 2000; Gray and Golowasch, 2016).

In the crayfish thoracic ganglion, rhythmic and alternating membrane potential oscillations that persisted in TTX were elicited by oxotremorine (Chrachri and Clarac, 1990) and in Clione rhythmic alternations thought to be important for locomotion also persisted in TTX (Arshavsky et al., 1985). Thus, in other rhythmically active motor networks, alternating activity patterns can also be generated without $\mathrm{Na}^{+}$-dependent processes. This may mean that sustaining rhythmic alternation in motor systems may be sufficiently important that there are multiple mechanisms that can do so.

\section{Neuronal targets of modulators that act on $I_{\mathrm{MI}}$}

Figure 9 summarizes the neuronal targets for five of the modulators studied here (Swensen and Marder, 2000, 2001). These data came from experiments in which modulators were applied to neurons isolated from descending modulatory inputs and from their connections with other pyloric neurons. Although each of the modulators activates the $I_{\mathrm{MI}}$ at the end of a second messenger signaling cascade, they act on their own receptor types. Figure $9 A$ shows that the $\mathrm{AB}$ and LP neurons responded to all five substances, the PD neuron showed robust responses to only three substances, and the LPG neurons showed responses to only two substances. The number of receptors shown in the diagram is an attempt to qualitatively capture the fact that the strengths of the responses were also different across cell types. Figure $9 B-E$ shows the complete set of neuronal targets for four of the substances that were studied here to help rationalize the differential TTX sensitivity of the rhythm to the applied substances, despite the fact that all of these substances activate $I_{\mathrm{MI}}$.

By analogy with the effects of TTX on bursting in a single neuron, it is plausible that each of the modulators studied here results in a rhythm that depends differentially on voltagedependent $\mathrm{Na}^{+}$currents and spike-mediated synaptic transmission. Both oxotremorine and CabTRP1a activate the AB, PD, and LPG neurons. We speculate that, by so doing, they activate the electrically coupled pyloric pacemaker ensemble sufficiently so that the pacemaker slow wave can drive the entire circuit with graded transmission. This is aided by the activation of the LP and PY neurons, in which $I_{\mathrm{MI}}$ enhances their ability to rebound from inhibition.

Although the phase and cycle frequency of the pyloric rhythm were conserved in oxotremorine in the presence of TTX, the frequency of the CabTRP1a rhythm was slower in the presence of TTX, and RPCH rhythms were highly variable. This demonstrates that graded synaptic transmission is, in principle, sufficient to establish and maintain a triphasic rhythm with phase relationships similar to the regular rhythm, but this will occur only under a specific set of modulatory conditions. Note that while RPCH activates the AB and LP neurons, it does not act on the PD, LPG, or PY neurons, so that it is likely that only AB and LP alternations will be sustained in TTX and RPCH, plausibly accounting for some of the properties of the RPCH rhythms.

Other modulators that activate $I_{\mathrm{MI}}$ were not able to generate rhythmic activity in the presence of TTX, presumably because they did not activate the pacemaker oscillators strongly enough 
A

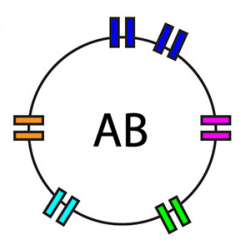

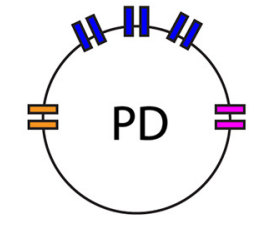

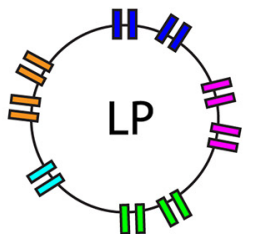

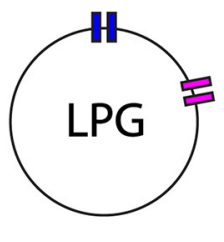

Oxotremorine

CabTRP1a

$\mathrm{RPCH} \quad$ पП

Proctolin पा

CCAP
B

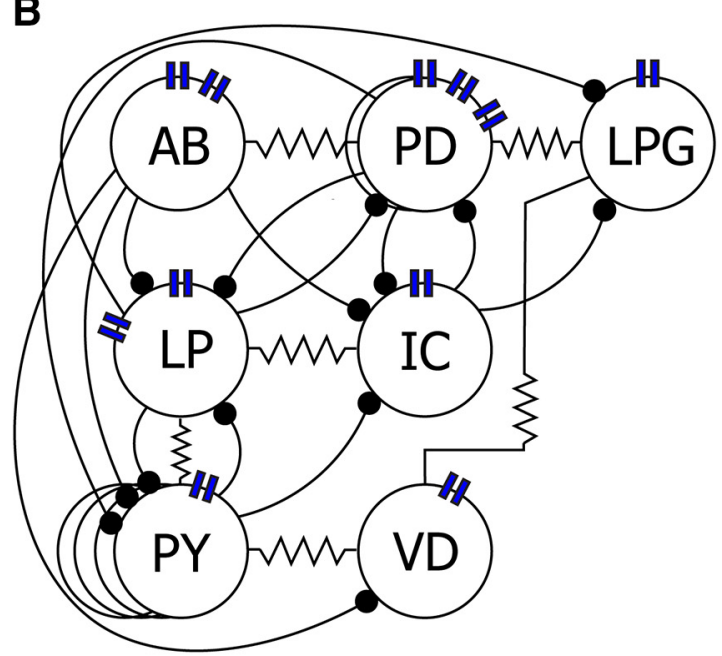

D

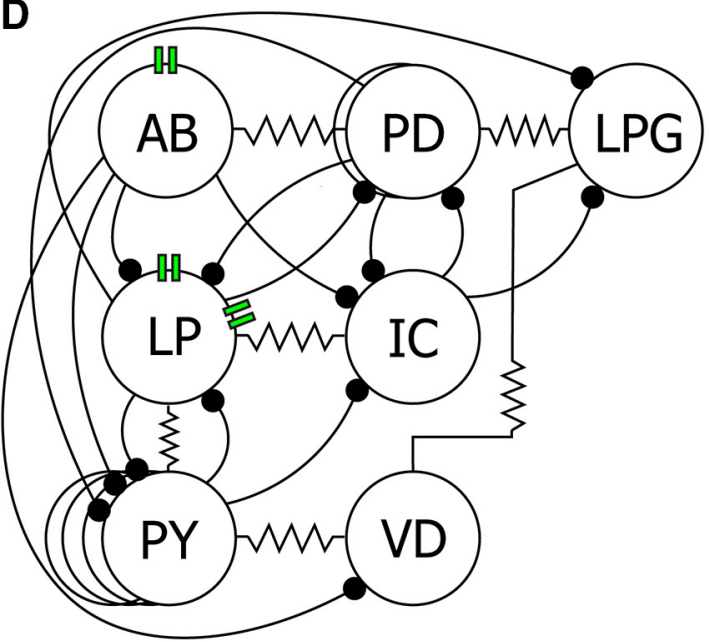

C



E

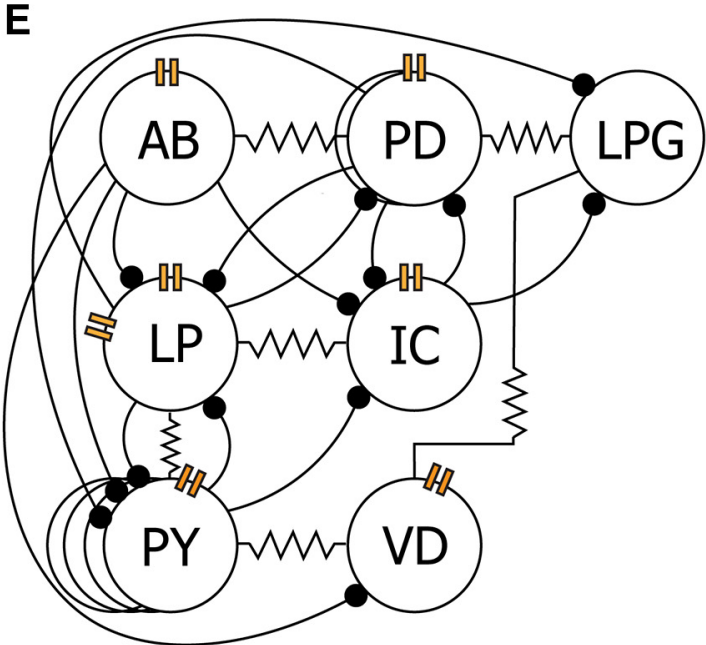

Figure 9. Schematic overview of STG neuron receptor distribution and circuit targets of different neuromodulators. $\boldsymbol{A}$, Receptor distribution for five substances onto four pyloric neurons. $\boldsymbol{B}-\boldsymbol{E}$, Distribution of oxotremorine $(\boldsymbol{B})$, CabTRP1a $(\boldsymbol{C}), \mathrm{RPCH}(\boldsymbol{D})$, and proctolin $(\boldsymbol{E})$ receptors on neurons of the pyloric circuit. The figure is a redrawn summary of data found in the studies by $S$ wensen and Marder $(2000,2001)$.

or evoke sufficient rebound from inhibition in the follower neurons.

\section{Sustaining rhythms with graded transmission}

There appear to be species differences in whether graded transmission alone can sustain the full triphasic pyloric rhythm. In $P$. interruptus, dopamine strongly activates the $\mathrm{AB}$ neuron (Marder and Eisen, 1984b; Flamm and Harris-Warrick, 1986b), and graded transmission is sufficient to maintain the triphasic rhythm in dopamine and TTX (Raper, 1979; Anderson and Barker, 1981). However, this is not the case in C. borealis. Given the fact that dopamine activates several receptors and modulates a variety of ionic conductances (Harris-Warrick and Johnson,
2010; Krenz et al., 2013), it is perhaps not surprising that this species difference is seen.

During robust STG activity, it has been estimated that substantially more transmitter is released as a graded function of the membrane potential of the presynaptic neurons than is released by action potentials (Raper, 1979; Graubard et al., 1980; Ross and Graubard, 1989). Graded synaptic transmission shows depression, and the response depends on the shape, amplitude, and frequency of the presynaptic stimulus (Manor et al., 1997; Kvarta et al., 2012). Because the threshold for graded transmitter release is quite hyperpolarized (Maynard and Walton, 1975; Manor et al., 1997) and the slow waves persist for hundreds of milliseconds, these slow and graded synaptic events result in large and pro- 
longed changes in postsynaptic conductance. Of course, spikes are necessary to convey information from the STG to the muscles that are driven by the STG motor neurons, but pattern generation depends primarily on analog signaling and benefits from the structure of STG neurons (Otopalik et al., 2017a,b).

\section{Modulation and complex dynamics}

Many cellular and neuronal processes that act on different time scales are directly or indirectly affected by neuromodulation. The modulation of $I_{\mathrm{MI}}$ can directly alter burst amplitude and frequency, and these changes can result in changes in synaptic strength and release, which in turn can influence, for example, the extent of synaptic depression. So, even if these modulators act primarily on a single current, the dynamics of the cellular and synaptic mechanisms that result in a particular circuit output may all be changed (Harris-Warrick and Marder, 1991; Ayali et al., 1998; Stein, 2009; Kvarta et al., 2012; Marder et al., 2014; Nadim and Bucher, 2014). Additionally, some modulators affect graded and spike-mediated transmission differently (Ayali et al., 1998). Some of the $I_{\mathrm{MI}}$ modulators may not generate a rhythm in TTX, if graded transmission is preferentially weakened and spikemediated transmission is enhanced. Even in a system that does not rely as heavily as the crustacean STG on graded transmission, a shifting of this balance might have large implications. Thus, the challenge for the future will be to understand in detail how all of the changes in network dynamics arise from the myriad cellular mechanisms called into play directly and indirectly. This is, of course, the same challenge that we face in understanding the dynamics of larger networks, but in larger networks it may be more difficult to discover the details of all of the targets of a given modulator and thus to understand, even qualitatively, how modulation occurs.

\section{References}

Anderson WW, Barker DL (1981) Synaptic mechanisms that generate network oscillations in the absence of discrete postsynaptic potentials. J Exp Zool 216:187-191. CrossRef Medline

Angstadt JD, Calabrese RL (1991) Calcium currents and graded synaptic transmission between heart interneurons of the leech. J Neurosci 11:746759. Medline

Arshavsky YuI, Beloozerova IN, Orlovsky GN, Panchin YuV, Pavlova GA (1985) Control of locomotion in marine mollusk clione-limacina. III. On the origin of locomotory rhythm. Exp Brain Res 58:273-284. Medline

Ayali A, Harris-Warrick RM (1999) Monoamine control of the pacemaker kernel and cycle frequency in the lobster pyloric network. J Neurosci 19:6712-6722. CrossRef Medline

Ayali A, Johnson BR, Harris-Warrick RM (1998) Dopamine modulates graded and spike-evoked synaptic inhibition independently at single synapses in pyloric network of lobster. J Neurophysiol 79:2063-2069. CrossRef Medline

Bal T, Nagy F, Moulins M (1994) Muscarinic modulation of a patterngenerating network: control of neuronal properties. J Neurosci 14:30193035. CrossRef Medline

Bidaut M (1980) Pharmacological dissection of pyloric network of the lobster stomatogastric ganglion using picrotoxin. J Neurophysiol 44:10891101. CrossRef Medline

Blitz DM, Christie AE, Coleman MJ, Norris BJ, Marder E, Nusbaum MP (1999) Different proctolin neurons elicit distinct motor patterns from a multifunctional neuronal network. J Neurosci 19:5449-5463. CrossRef Medline

Bonansco C, Buño W (2003) Cellular mechanisms underlying the rhythmic bursts induced by NMDA microiontophoresis at the apical dendrites of CA1 pyramidal neurons. Hippocampus 13:150-163. CrossRef Medline

Burrows M, Siegler MV (1978) Graded synaptic transmission between local interneurons and motor neurons in the metathoracic ganglion of the locust. J Physiol 285:231-255. CrossRef Medline

Chrachri A, Clarac F (1990) Fictive locomotion in the 4th thoracic ganglion of the crayfish, Procambarus clarkii. J Neurosci 10:707-719. CrossRef Medline

Christie AE, Lundquist CT, Nässel DR, Nusbaum MP (1997) Two novel tachykinin-related peptides from the nervous system of the crab Cancer borealis. J Exp Biol 200:2279-2294. Medline

DiCaprio RA (1989) Nonspiking interneurons in the ventilatory central pattern generator of the shore crab, Carcinus maenas. J Comp Neurol 285:83-106. CrossRef Medline

DiCaprio RA (2003) Nonspiking and spiking proprioceptors in the crab: nonlinear analysis of nonspiking TCMRO afferents. J Neurophysiol 89: 1826-1836. CrossRef Medline

Dickinson PS, Nagy F (1983) Control of a central pattern generator by an identified modulatory interneurone in crustacea. II. induction and modification of plateau properties in pyloric neurones. J Exp Biol 105:59-82. Medline

Dickinson PS, Mecsas C, Marder E (1990) Neuropeptide fusion of two motor pattern generator circuits. Nature 344:155-158. CrossRef Medline

Eisen JS, Marder E (1982) Mechanisms underlying pattern generation in lobster stomatogastric ganglion as determined by selective inactivation of identified neurons. III. Synaptic connections of electrically coupled pyloric neurons. J Neurophysiol 48:1392-1415. CrossRef Medline

Eisen JS, Marder E (1984) A mechanism for production of phase shifts in a pattern generator. J Neurophysiol 51:1375-1393. CrossRef Medline

Elson RC, Selverston AI (1992) Mechanisms of gastric rhythm generation in the isolated stomatogastric ganglion of spiny lobsters: bursting pacemaker potentials, synaptic interactions, and muscarinic modulation. J Neurophysiol 68:890-907. CrossRef Medline

Epstein IR, Marder E (1990) Multiple modes of a conditional neural oscillator. Biol Cybern 63:25-34. CrossRef Medline

Flamm RE, Harris-Warrick RM (1986a) Aminergic modulation in lobster stomatogastric ganglion. I. Effects on motor pattern and activity of neurons within the pyloric circuit. J Neurophysiol 55:847-865. CrossRef Medline

Flamm RE, Harris-Warrick RM (1986b) Aminergic modulation in lobster stomatogastric ganglion. II. Target neurons of dopamine, octopamine, and serotonin within the pyloric circuit. J Neurophysiol 55:866-881. CrossRef Medline

Garcia VJ, Daur N, Temporal S, Schulz DJ, Bucher D (2015) Neuropeptide receptor transcript expression levels and magnitude of ionic current responses show cell type-specific differences in a small motor circuit. J Neurosci 35:6786-6800. CrossRef Medline

Goaillard JM, Taylor AL, Schulz DJ, Marder E (2009) Functional consequences of animal-to-animal variation in circuit parameters. Nat Neurosci 12:1424-1430. CrossRef Medline

Golowasch J, Marder E (1992) Proctolin activates an inward current whose voltage dependence is modified by extracellular $\mathrm{Ca}^{2+}$. J Neurosci 12:810817. CrossRef Medline

Grashow R, Brookings T, Marder E (2009) Reliable neuromodulation from circuits with variable underlying structure. Proc Natl Acad Sci U S A 106: 11742-11746. CrossRef Medline

Grashow R, Brookings T, Marder E (2010) Compensation for variable intrinsic neuronal excitability by circuit-synaptic interactions. J Neurosci 30:9145-9156. CrossRef Medline

Graubard K (1978) Synaptic transmission without action potentials: inputoutput properties of a non-spiking presynaptic neuron. J Neurophysiol 41:1014-1025. CrossRef Medline

Graubard K, Raper JA, Hartline DK (1980) Graded synaptic transmission between spiking neurons. Proc Natl Acad Sci U S A 77:3733-3735. CrossRef Medline

Gray M, Golowasch J (2016) Voltage dependence of a neuromodulatoractivated ionic current. eNeuro 3:0038-0016.2016. CrossRef Medline

Gray M, Daudelin DH, Golowasch J (2017) Activation mechanism of a neuromodulator-gated pacemaker ionic current. J Neurophysiol 118: 595-609. CrossRef Medline

Grillner S, Wallen P, Dale N, Brodin L, Buchanan J, Hill R (1987) Transmitters, membrane-properties and network circuitry in the control of locomotion in lamprey. Trends Neurosci 10:34-41. CrossRef

Gutierrez GJ, Grashow RG (2009) Cancer borealis stomatogastric nervous system dissection. J Vis $\operatorname{Exp}(25):$ e1207. CrossRef Medline

Hamood AW, Marder E (2014) Animal-to-animal variability in neuromodulation and circuit function. Cold Spring Harb Symp Quant Biol 79:21-28. CrossRef Medline 
Hamood AW, Marder E (2015) Consequences of acute and long-term removal of neuromodulatory input on the episodic gastric rhythm of the crab Cancer borealis. J Neurophysiol 114:1677-1692. CrossRef Medline

Hamood AW, Haddad SA, Otopalik AG, Rosenbaum P, Marder E (2015) Quantitative reevaluation of the effects of short- and long-term removal of descending modulatory inputs on the pyloric rhythm of the crab, Cancer borealis. eNeuro 2:e0058. CrossRef Medline

Harris-Warrick RM, Flamm RE (1987) Multiple mechanisms of bursting in a conditional bursting neuron. J Neurosci 7:2113-2128. CrossRef Medline

Harris-Warrick RM, Johnson BR (2010) Checks and balances in neuromodulation. Front Behav Neurosci 4:47. CrossRef Medline

Harris-Warrick RM, Marder E (1991) Modulation of neural networks for behavior. Annu Rev Neurosci 14:39-57. CrossRef Medline

Harris-Warrick RM, Coniglio LM, Levini RM, Gueron S, Guckenheimer J (1995) Dopamine modulation of two subthreshold currents produces phase shifts in activity of an identified motoneuron. J Neurophysiol 74: 1404-1420. CrossRef Medline

Hartline DK (1979) Pattern generation in the lobster (Panulirus) stomatogastric ganglion. II. Pyloric network simulation. Biol Cybern 33:223-236. CrossRef Medline

Hartline DK, Gassie DV Jr (1979) Pattern generation in the lobster (Panulirus) stomatogastric ganglion. I. Pyloric neuron kinetics and synaptic interactions. Biol Cybern 33:209-222. CrossRef Medline

Hooper SL, Marder E (1984) Modulation of a central pattern generator by two neuropeptides, proctolin and FMRFamide. Brain Res 305:186-191. CrossRef Medline

Hooper SL, Thuma JB, Guschlbauer C, Schmidt J, Büschges A (2015) Cell dialysis by sharp electrodes can cause nonphysiological changes in neuron properties. J Neurophysiol 114:1255-1271. CrossRef Medline

Johnson BR, Harris-Warrick RM (1990) Aminergic modulation of graded synaptic transmission in the lobster stomatogastric ganglion. J Neurosci 10:2066-2076. CrossRef Medline

Johnson BR, Peck JH, Harris-Warrick RM (1995) Distributed amine modulation of graded chemical transmission in the pyloric network of the lobster stomatogastric ganglion. J Neurophysiol 174:437-452. CrossRef Medline

Johnson BR, Brown JM, Kvarta MD, Lu JY, Schneider LR, Nadim F, HarrisWarrick RM (2011) Differential modulation of synaptic strength and timing regulate synaptic efficacy in a motor network. J Neurophysiol 105:293-304. CrossRef Medline

Kadiri LR, Kwan AC, Webb WW, Harris-Warrick RM (2011) Dopamineinduced oscillations of the pyloric pacemaker neuron rely on release of calcium from intracellular stores. J Neurophysiol 106:1288-1298. CrossRef Medline

Kilman VL, Marder E (1996) Ultrastructure of the stomatogastric ganglion neuropil of the crab, Cancer borealis. J Comp Neurol 374:362-375. CrossRef Medline

Krenz WD, Hooper RM, Parker AR, Prinz AA, Baro DJ (2013) Activation of high and low affinity dopamine receptors generates a closed loop that maintains a conductance ratio and its activity correlate. Front Neural Circuits 7:169. CrossRef Medline

Kvarta MD, Harris-Warrick RM, Johnson BR (2012) Neuromodulatorevoked synaptic plasticity within a central pattern generator network. J Neurophysiol 108:2846-2856. CrossRef Medline

MacLean JN, Schmidt BJ (2001) Voltage-sensitivity of motoneuron NMDA receptor channels is modulated by serotonin in the neonatal rat spinal cord. J Neurophysiol 86:1131-1138. CrossRef Medline

Manor Y, Nadim F, Abbott LF, Marder E (1997) Temporal dynamics of graded synaptic transmission in the lobster stomatogastric ganglion. J Neurosci 17:5610-5621. CrossRef Medline

Marder E (2012) Neuromodulation of neuronal circuits: back to the future. Neuron 76:1-11. CrossRef Medline

Marder E, Bucher D (2007) Understanding circuit dynamics using the stomatogastric nervous system of lobsters and crabs. Annu Rev Physiol 69: 291-316. CrossRef Medline

Marder E, Calabrese RL (1996) Principles of rhythmic motor pattern generation. Physiol Rev 76:687-717. CrossRef Medline

Marder E, Eisen JS (1984a) Transmitter identification of pyloric neurons: electrically coupled neurons use different neurotransmitters. J Neurophysiol 51:1345-1361. CrossRef Medline

Marder E, Eisen JS (1984b) Electrically coupled pacemaker neurons re- spond differently to same physiological inputs and neurotransmitters. J Neurophysiol 51:1362-1374. CrossRef Medline

Marder E, Hooper SL (1985) Neurotransmitter modulation of the stomatogastric ganglion of decapod crustaceans. In: Model neural networks and behavior (Selverston AI, ed), pp 319-337. New York, NY: Plenum.

Marder E, Paupardin-Tritsch D (1978) The pharmacological properties of some crustacean neuronal acetylcholine, gamma-aminobutyric acid, and L-glutamate responses. J Physiol 280:213-236. CrossRef Medline

Marder E, Weimann JM (1992) Modulatory control of multiple task processing in the stomatogastric nervous system. In: Neurobiology of motor progamme selection (Kien J, McCrohan C, Winlow B, eds), pp 3-19. New York: Pergamon.

Marder E, Hooper SL, Siwicki KK (1986) Modulatory action and distribution of the neuropeptide proctolin in the crustacean stomatogastric nervous system. J Comp Neurol 243:454-467. CrossRef Medline

Marder E, Hooper SL, Eisen JS (1987) Multiple neurotransmitters provide a mechanism for the production of multiple outputs from a single neuronal circuit. In: Synaptic function (Edelman GM, Gall WE, Cowan MW, eds), pp 305-327. New York, NY: Wiley.

Marder E, O'Leary T, Shruti S (2014) Neuromodulation of circuits with variable parameters: single neurons and small circuits reveal principles of state-dependent and robust neuromodulation. Annu Rev Neurosci 37: 329-346. CrossRef Medline

Maynard DM (1972) Simpler networks. Ann NY Acad Sci 193:59-72. CrossRef Medline

Maynard DM, Walton KD (1975) Effects of maintained depolarization of presynaptic neurons on inhibitory transmission in lobster neuropil. J Comp Physiol 97:215-243. CrossRef

Miller JP, Selverston AI (1982) Mechanisms underlying pattern generation in lobster stomatogastric ganglion as determined by selective inactivation of identified neurons. II. Oscillatory properties of pyloric neurons. J Neurophysiol 48:1378-1391. CrossRef Medline

Nadim F, Bucher D (2014) Neuromodulation of neurons and synapses. Curr Opin Neurobiol 29: 48-56. CrossRef Medline

Nusbaum MP, Marder E (1988) A neuronal role for a crustacean red pigment concentrating hormone-like peptide: neuromodulation of the pyloric rhythm in the crab, Cancer borealis. J Exp Biol 135:165-181.

Otopalik AG, Sutton AC, Banghart M, Marder E (2017a) When complex neuronal structures may not matter. Elife 6:e23508. CrossRef Medline

Otopalik AG, Goeritz ML, Sutton AC, Brookings T, Guerini C, Marder E (2017b) Sloppy morphological tuning in identified neurons of the crustacean stomatogastric ganglion. Elife 6:e22352. CrossRef Medline

Pearson KG, Fourtner CR (1975) Nonspiking interneurons in walking system of the cockroach. J Neurophysiol 38:33-52. CrossRef Medline

Prime L, Pichon Y, Moore LE (1999) N-methyl-D-aspartate-induced oscillations in whole cell clamped neurons from the isolated spinal cord of Xenopus laevis embryos. J Neurophysiol 82:1069-1073. CrossRef Medline

Rabbah P, Nadim F (2005) Synaptic dynamics do not determine proper phase of activity in a central pattern generator. J Neurosci 25:11269 11278. CrossRef Medline

Raper JA (1979) Nonimpulse-mediated synaptic transmission during the generation of a cyclic motor program. Science 205:304-306. CrossRef Medline

Ross WN, Graubard K (1989) Spatially and temporally resolved calcium concentration changes in oscillating neurons of crab stomatogastric ganglion. Proc Natl Acad Sci U S A 86:1679-1683. CrossRef Medline

Russell DF (1979) CNS control of pattern generators in the lobster stomatogastric ganglion. Brain Res 177:598-602. CrossRef Medline

Selverston AI, Miller JP (1980) Mechanisms underlying pattern generation in the lobster stomatogastric ganglion as determined by selective inactivation of identified neurons. I. Pyloric neurons. J Neurophysiol 44:11021121. CrossRef Medline

Selverston AI, Moulins M (1985) Oscillatory neural networks. Annu Rev Physiol 47:29-48. CrossRef Medline

Sharp AA, O'Neil MB, Abbott LF, Marder E (1993) The dynamic clamp: artificial conductances in biological neurons. Trends Neurosci 16:389394. CrossRef Medline

Shu Y, Hasenstaub A, Duque A, Yu Y, McCormick DA (2006) Modulation of intracortical synaptic potentials by presynaptic somatic membrane potential. Nature 441:761-765. CrossRef Medline

Sigvardt KA, Grillner S, Wallén P, Van Dongen PA (1985) Activation of 
NMDA receptors elicits fictive locomotion and bistable membrane properties in the lamprey spinal cord. Brain Res 336:390-395. CrossRef Medline

Soofi W, Goeritz ML, Kispersky TJ, Prinz AA, Marder E, Stein W (2014) Phase maintenance in a rhythmic motor pattern during temperature changes in vivo. J Neurophysiol 111:2603-2613. CrossRef Medline

Stein W (2009) Modulation of stomatogastric rhythms. J Comp Physiol A 195:989-1009. CrossRef Medline

Stein W, DeLong ND, Wood DE, Nusbaum MP (2007) Divergent cotransmitter actions underlie motor pattern activation by a modulatory projection neuron. Eur J Neurosci 26:1148-1165. CrossRef Medline

Swensen AM, Marder E (2000) Multiple peptides converge to activate the same voltage-dependent current in a central pattern-generating circuit. J Neurosci 20:6752-6759. CrossRef Medline

Swensen AM, Marder E (2001) Modulators with convergent cellular actions elicit distinct circuit outputs. J Neurosci 21:4050-4058. CrossRef Medline

Thirumalai V, Prinz AA, Johnson CD, Marder E (2006) Red pigment con- centrating hormone strongly enhances the strength of the feedback to the pyloric rhythm oscillator but has little effect on pyloric rhythm period. J Neurophysiol 95:1762-1770. CrossRef Medline

Weimann JM, Marder E, Evans B, Calabrese RL (1993) The effects of SDRNFLRFamide and TNRNFLRFamide on the motor patterns of the stomatogastric ganglion of the crab Cancer borealis. J Exp Biol 181:1-26. Medline

Weimann JM, Skiebe P, Heinzel HG, Soto C, Kopell N, Jorge-Rivera JC, Marder E (1997) Modulation of oscillator interactions in the crab stomatogastric ganglion by crustacean cardioactive peptide. J Neurosci 17: 1748-1760. CrossRef Medline

Wood DE, Stein W, Nusbaum MP (2000) Projection neurons with shared cotransmitters elicit different motor patterns from the same neuronal circuit. J Neurosci 20:8943-8953. CrossRef Medline

Zhao S, Sheibanie AF, Oh M, Rabbah P, Nadim F (2011) Peptide neuromodulation of synaptic dynamics in an oscillatory network. J Neurosci 31:13991-14004. CrossRef Medline 